\title{
CONTRASTING MARKED AND UNMARKED QUESTIONS: A CASE OF SIH IN INDONESIAN
}

\author{
Rika Mutiara \\ Universitas Esa Unggul \\ rika.mutiara@esaunggul.ac.id
}

\begin{abstract}
The discourse marker sih is a common feature of questions in colloquial Indonesian. Results of previous research show there is a contrastive function of $s i h$ in questions. The questions in which sih occurs arecalled marked questions. The present study explores the functions of sih by contrasting marked and unmarked questions produc ed by the same speakers. The marked questions can occur before the unmarked questions or in reverse order. In both patterns, the marked questions indicate speakers' great willing ness to know ab out something. They also show speakers' way to attract the attention of the hearers. The unmarked questions were used when the speakers elicit more accurate ans wers. Moreover, they were uttered when the hearers do not get theidea mentioned in the first question. They were uttered because the hearers' ask for repetition.
\end{abstract}

Key words: discourse marker sih, questions, Indonesian

\section{Abstrak}

Penanda wacana sih adalahfitur yang umum ditemui dalam pertanyaan bahas a In done sia sehari-hari. Penelitian sebelumnya menunjukkan fungsi yang bertentang an mengenai si dalampertanyaan. Pertanyaan yang mengandung sih disebut sebagai pertanyaan yang ditandai. Penelitian ini mengkajifungsi sih dengan caramembandingkan pertanyaan yang ditandai dengan sih dan yang tidak. Keduajenispertanyaan tersebut diucapkan oleh penutur yang sama. Pertanyaan yang ditandai dengan sih dapatmunculmendahuluipertanyaan yang tidak ditandai dengan sihatau sebaliknya. Pada kedua pola tersebut, pertanyaan yang ditandai dengan sihmenunjukkan keinginan yang besardari penutur untuk mengetahui suatu hal. Pertanyaanjenis inijugaberguna untukmenarik perhatian pendengar. Pertanyaan yang tidak ditandai dengan sih digunakan ketika penutur meng inginkan jawaban yang lebih tepat dan pasti. Selain itu, pertanyaan inimuncul sebagai respon penutur terhadap pendengar yang meminta pengulangan. Pendengar tidak menangkap makna pada pertanyaan pertama.

Kata kunci: penanda wacana sih, pertanyaan, bahasa Indonesia

\section{INTRODUCTION}

Discourse marker (DM) is a prominent feature in conversation that carries several functions depending on the context. DM has pragmatic meaning which shows what happens between the participants involved in the conversation and the message they deliver (Biber et al., 1999). Moreover, it represents the attitudes of the participants in conversation (Östman, Jan-Ola $\&$ Virtanen, 2011). The speakers used DMs to assist the hearers to understand what they mean. 
How the speakers facilitate each other in achieving the goal of the discourse was conducted through DM (Rühlemann, 2006).

There are several DMs in Indonesian such as kan, ya, sih, deh, kok, etc. The DMs might occur in affirmative and interrogative utterances. Some scholars have conducted studies on the DM sih. There could be different functions if they occur in affirmative or interrogative utterances. The present study examined the questions marked with sih in colloquial Jakartan Indonesian. The DM sih tends to occur in the final position of utterances and it is used in questions with question words apa, kenapa, di mana, mengapa, gimana, etc. The present study specifically focused in the interrogative utterances with the question word apa.

The occurrence of sih has attracted the interest of some scholars. Miyake (2015), for example, exemplifies sih in questions which indicate the speakers' complaints or dislikes.

$\begin{array}{llll}\text { Laki-laki } & \text { gimana, } & \text { sih, } & \text { ya? } \\ \text { man } & \text { how } & \text { sih } & \text { yeah }\end{array}$

'What kind of man is he, sih, yeah?'

$\begin{array}{llll}\text { Isinya } & \text { apa } & \text { aja } & \text { sih? } \\ \text { content-nya } & \text { what } & \text { just } & \text { sih } \\ \text { 'What's inside, sih?' } & & \end{array}$

'What's inside, sih?'

In a different note, Sneddon (2006) claims that sih is used to demonstrate that the speakers have less interest in the issue and that it has a softening effect, as in the following examples:

Lo ama Bowo uda berapa lama, sih?
you with Bowo already how long sih

'How long have you been going out with Bow o, sih?'

Tau dari mana, sih?

know from where sih

'From where did you hear (that), sih?'

In contrast, Djenar, Ewing, \& Manns (2018) state that sih is used when the speakers are looking forw ard to hearing the responses from the hearers. Observe the following:

Kok mesti pake nama samaran segala sih?"

'Why do (you) have to use an alias and all, can you tell me?'

Furthermore, Sari (2009) paid attention to the intonation of the utterances with sih. She noticed that $s i h$ in questions occur with a rising intonation. In this case, sih is intended to urge the hearers' responses. Questions marked with sih represent speakers' eagerness to discover the answer, as seen in the following examples.

Di mana sih kosnya?

'Where is $[\operatorname{sih}]$ your rented place?'

Berapa sih sebulan?

'How much $[s i h]$ is the rent per month?' 
The previous studies mentioned above show contrastive results. According to Djenar et al. (2018) \& Sari (2009), the function of sih is to urge the hearers to give responses while for Sneddon (2006), the speakers do not give much concern on the topic being asked. It is therefore necessary to conduct another study on the function of $s i h$ in questions. The studies discussed above focus on the single occurence of marked questions with sih. Preliminary finding of the present study uncovers that when the speakers use apa sih, they also produced other ques tions which concern on the same issue with the questions they have produced before. Those questions tend to be unmarked since sih was not applied. Observe the following examples.
A: Ini apa sih namanya nih?
this what sih name-its this
'What's sih its name?'
B: Heh?
Exc
'Huh?'
A: Ini apa namanya?
this what name-its
'What's its name?'

First, A produced a question marked with sih. B responded by saying heh. Then, A asked again. The second question was unmarked. Sih was used only in the first question. An analysis of how the interlocutors responded to those types of questions (marked and unmarked questions) would give a better understanding of the meaning of sih in questions. Therefore, the analysis in the present study begins with the functions of marked and unmarked questions and how the interlocutors respond to them.

Based on the results of previous studies (Djenar et al., 2018; Sari, 2009), it c an be said that the questions with sih are intended to seek information. In seeking information, the speakers put themselves in a particular epistemic status. This means that the way the speakers produce the questions - whether the questions occur with DMs or not - indicate how they place their own status and the hearers' status, those who are in more knowledgable and less know ledgable positions (Heritage, 2013).

Such issue has been explored by Hamdani \& Barnes (2018). The study focused on polar questions with the DMs ya and kan. DMs in the final positions sign the marked polar questions in Indonesian. The ones marked with ya represent epistemic asymmetry in whic h the speakers have more knowledge than the hearers while the ones marked with kan have more symmetrical knowledge among the speakers and the hearers. The DMs are prominent in questions because they emphasize the functions of questions in the utterances. The DMs were intentionally added to the questions because the speakers' goal is to make the hearers aw are of their questions.

Following the previous studies of Djenar et al., 2018 and Hamdani \& Barnes, 2018, the study applied conversation analysis. Conversation analysis was conducted in sequence organization (Mazeland, 2006; Schegloff, 2007). The participants organize their utterances based on reasoning skills they did towards utterances produced by other participants. In making meaning of the utterances, the participants could do some strategies such as respecifying their utterances and renegotiating (Mazeland, 2006). The impact to the present study is that the order of giving and accepting information in questions should be scrutinized briefly. Participants 
organize the interaction in such a good way (Sidnell, 2015). Furthermore, conversation analy sis concerns on the way the speakers understand each other in their turn taking. In doing the analysis, special attention was given to the way the speakers respond to previous utterances. Speakers' responses were based on their comprehension of the utterances produced by other participants (Koshik, 2003).

As this study focuses on the questions and answers, the principle of adjacency pair w as observed in the analysis. In adjacency pairs, the second part cannot stand alone; its mes s age is relevant to the utterance in the first part. An example of adjacency pair is question and answer. The answer cannot be separated from the question. The ways the speakers organize their utterances give implications to the participants (Mazeland, 2006; Schegloff, 2007; Sidnell, 2015). When the speakers do not get an answer, they will apply some strategies such as pursuing an answer by changing the questions, drawing an inference why the other participants do not answer or reporting that their questions are not answered (Sidnell, 2015). Brown (2010) argued that some questions in Tzeltal aim at finding new information, confirmation, and repetetion that is due to its unclarity. Other questions function to assess, suggest, request, and offer. Bongelli et al. (2018) explored the question and epistemic position of questions in Italian. They found that WH questions indicate speakers' position of not knowing something; while polar, tag, and declarative questions show speakers' position of uncertainty. When the speakers are in the position of not knowing, they seek for information. The same issue has been discussed by Enfield (2010). WH questions aim at information seeking and repair. The present study focuses on one type of WHquestions namely apa (what).

The aim of the present study is to examine whether sih functions to encourage the hearers to give responses or not by contrasting marked and unmarked questions. In addition, it analyzed how speakers position themselves and their interlocutors in terms of epistemic in seeking for information. Previous study of participant' epistemic in marked and unmarked questions only discussed DM kan and ya. The present study extends the discussion of such issue by analyzing the DM sih.

\section{METHODOLOGY}

The data were taken from the CHILDES (Child Language Data Exchange System). The participants in the interactions are children and adults. The children talked about various topic $\mathrm{s}$ to adults or other children in colloquial Jakartan Indonesian, a variety that is commonly used among those living in Jakarta. Antconc, a concordance tool, was used in the present study to find the collocations of apa and sih. Because sih occurs in the final position in questions, the span of finding the collocations is four words to the right of apa. The concordance lines were examined to find the conversation in which the marked questions with sih co-occur with other unmarked questions. Following the previous studies on DMs, $s i h$ was not translated into English in the transcription to maintain the actual sense it carries (Djenar et al., 2018; Hamdani \& Barnes, 2018; Miyake, 2015; Sari, 2009).

Twenty three extracts of conversation were analyzed to prove whether sih functions to encourage the hearers to respond the questions and find out the positions of the speakers and the hearers. It was done in the level of Turn Constructional Unit (TCU). Consideration to the presupposition of the questions, question design, social action and preference organization w as conducted (Bongelli et al., 2018). Then, in each extract, the patterns of occurrences of marked 
and unmarked questions were identified. The possible patterns are marked-unmarked in which marked questions were followed by the unmarked questions or unmarked-marked where unmarked questions proceeded the marked questions. Then, as final markers, the lexical surrounding of sih was analyzed. It concerns on whether some nouns such as address terms or pronouns followed sih in questions. Next, the questions produced by same speakers and the responses were examined.

\section{FINDINGS AND DISCUSSION}

Among the 23 conversation extracts, the pattern of marked questions followed by unmarked questions was found in 16 extracts. The pattern of marked questions proceeded by unmarked questions exists in four extracts. The rest three extracts have various patterns. They have three questions. The patterns are varied as marked-unmarked-unmarked, unmarked-markedunmarked, and unmarked-unmarked-marked. Sih occurs when the speakers seek information. They try to find the most relevant answer. It is in line with the findings in the previous studies (Djenar et al., 2018; Sari, 2009). The finding of the present study supports the idea that DMs in questions function to make the interlocutors sense the request to give information to those who seek for information (Hamdani \& Barnes, 2018).

In some extracts, some common lexical features in colloquial Indonesian occur in the questions marked with sih. Aja (just) was applied in a question as in belajar apa aja sih? Three questions have memang (actually). In colloquial Jakartan, memang appears as emangnya and mang. The speakers asked emangnya dia pegang apa sih? and mang McD ada apa sih Ca? It indicates speaker's seriousness in asking. Those features give a contribution to the meaning of utterances marked with sih.

\section{Functions of the Marked and Unmarked Questions}

This part begins by presenting an analysis of marked-unmarked qustions. As can be see in extract (1), the participants were talking about an object. The first question uttered by A was marked with sih. In this case, A tried to attract B's attention in order to get some information. B said the crab was so cute. For him, it could be a pudding mold. The next question was not marked with sih. B replied that it was a pudding mold, but he added the word kali 'maybe'. The question marked with sih was uttered to get the answer about the name of the object. Since B's answer did not satisfy A, he asked again for a more definite answer. In this case, he pursued for a more precise response.

\section{Extract 1}

A: Ini apa sih, inih?

this what sih this

'What is this sih, this one?'

$\begin{array}{clllll}\text { B: Idih, lucu } & \text { banget kepitingnya. } & \text { Ini } & \text { mah } & \text { tempat ager-ager } & \text { kali. } \\ \text { exc cute } & \text { very crab-nya } & \text { this } & \text { DM } & \text { mold pudding } & \text { maybe }\end{array}$ 'Wow, how cute the crab is. Well, it's probably a pudding mold.' 
A: Ini apaan inih?

this what this

'What is this?'

$\begin{array}{cl}\mathrm{B}: \text { Tempat } & \text { ager-ager. } \\ \text { mold } & \text { pudding }\end{array}$

'A pudding mold.'

Extract (2) has a different pattern. It is a marked question followed by two unmarked questions. The extract shows that the participants talked about a picture. The first question is marked with DM sih. A answered the question with Heli. As a note, Heli is a famous Indonesian children song about a pet dog named Heli. Thus, what A meant was a dog. B asked again a couple of times about what it was and got the same answer. Of the three questions with apa, only the first question was marked with sih, indicating that he was eager to know whether B understood the name of the object. Since B kept repeating that the name of the object w as Heli, A finally explained that it was not Heli but a Dalmatian. Unlike the marked question with sih that was meant to show A's enthusiasm for B's response, the unmarked questions were uttered to direct the interlocutor to reconsider for another possible answer (see Djenar et al., 2018; Hamdani \& Barnes, 2018; Sari, 2009).

Extract 2

B: Gambarnya apa sih? picture-nya what sih 'What picture is it sih?'

A: Heli.

Heli.

'Heli'

B: Apa?

what

'What?'

A: Heli.

Heli

'Heli'

B: Apa?

what

'What?'

A: Heli.

Heli

'Heli'

B: Heli? Bukan. Dalmatian ini.

Heli (?). No Dalmatian this

'Heli? No. It's Dalmatian.'

A: Guguk.

$\operatorname{dog}$

'Dog.' 
B: Iya. Pernah nonton itu nggak filem Dalmatian, hm? yes ever watch that not movie Dalmatian exc Yes. Have you watched a Dalmatian movie before? Hm.

A: Udah.

already

'I have'

In the following case (Extract 3), A was surprised as B (the child) can speak in Englis h. A asked B who taught her English. B said it was her English teacher at school. The next question was marked with sih (Belajar apa aja sih?) in order to get some information from B. However, A did not get a satisfactory response and therefore he asked again with an unmarked question. This question was meant to get more accurate information.

\section{Extract 3}

A: We, Ica sekarang udah bisa basa Inggris, ya iya? wowIca now already can language. English yes yes

'Wow. Ica can speak English now. Who taught you?'

A: Sapa yang ngajarin?

who which teach

'Who teach (you)?'

B: Kan ada guru basa Inggris.

DM exist teacher language English

'An English teacher'

A: Di sekolahan?

at school

'At school?'

B: Tar di sekolah madrasah.

later at school madrassa

'Later at madrassa'

A: Sekolah madrasah mana?
school madrassa which
'Which madrassa?'

B: Madrasah Asem.

madrassa Asem

'Madrassa Asem'
A: Iya?
Yes
'Yes'
C: Aku juga.
I too
'Me, too.'
A: Belajar apa aja sih?
study what just sih?
'What have you learnt, sih?'




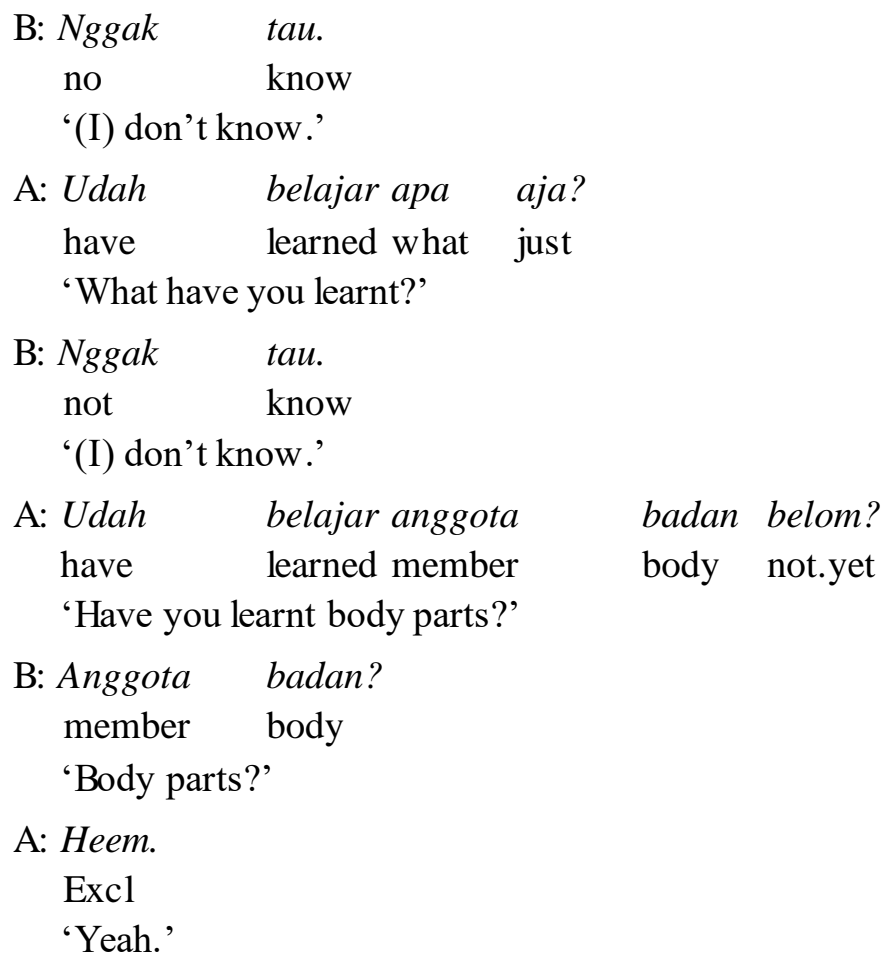

In the three examples discussed above, the speakers uttered marked questions bec ause they would like to express their great wish to hear the answers. This finding is relevant to the ones reported by Djenar et al., (2018); Hamdani \& Barnes (2018); and Sari, (2009). When the interlocutors do not give a relevant answer, they will ask again. The next questions they produced were unmarked. The speakers know the interlocutors realize the points of the questions and the urgency to get an accurate answer. Therefore, there is no need to make the interlocutors aware of those points with DM sih. The unmarked questions demand the interlocutors to give answers that are in line with the expectations of the person who asks the question.

The next two cases discussed unmarked questions that occur before the marked ones. Extract (4) is a conversation of a kid who was stung by an ant. A said that Ngki's foot was stung by an ant. $\mathrm{B}$ and $\mathrm{C}$ responded by requesting to see it. $\mathrm{C}$ then asked what type of ant it $\mathrm{w}$ as, and the question was unmarked. A responded by showing the swollen foot and telling again it was stung by an ant. Because $\mathrm{C}$ did not get the answer of what type of ant it was, he then asked the same question again. This time, the question was marked with sih, showing his eagerness to get the information about the type of ant. The question was successful in getting A's attention. A helped by asking what type of ant it was. D then proposed an idea that it was a red ant.

\section{Extract 4}

$\begin{array}{llllll}\text { A: } C a \text {, tuh Ngki digigit semut katanya tuh, kakinya } & \text { tuh. } \\ \mathrm{Ca} \text { that Ngki biten ant word-nya that } & \text { feet-his } & \text { that } \\ \text { 'Ca, look! Ngki was stung by an ant. Look at his feet.' } & & \end{array}$
B: Mana, mana?
which which

'Let me see, which one?' 


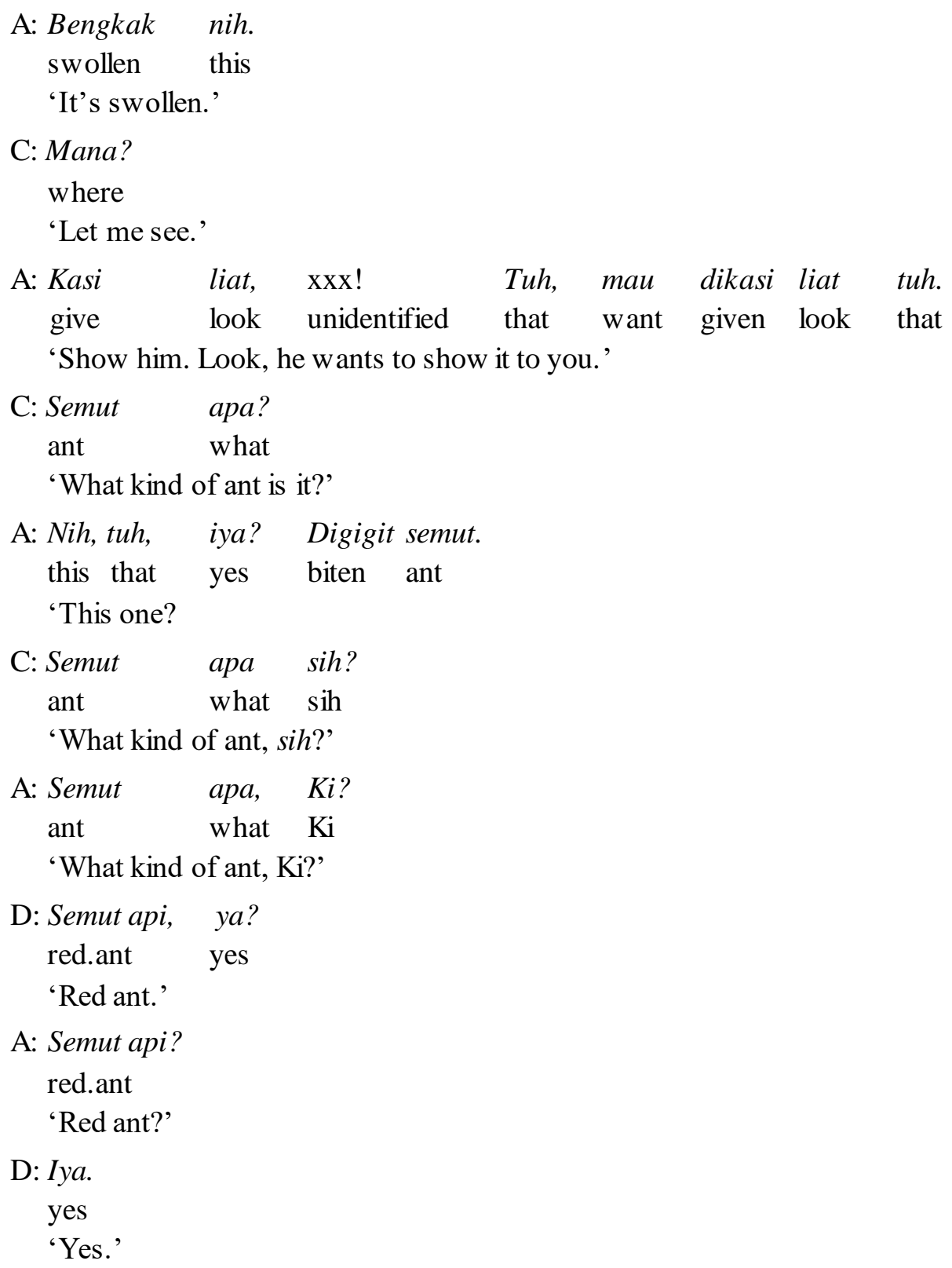

In the following extract, A showed a pole to B by saying that it was a pole. However, it seems that B did not understand what A meant to say, and therefore A repeated the information he had given before. B said that it was not a pole and then asked $\mathrm{C}$ what it was. C only responded by saying heh. Then, B asked again apa sih itu. In this case sih carries the sense of a serious question that needs to be answered (Djenar et al., 2018; Sari, 2009). B w anted to raise raise C's awareness towards his question (Hamdani \& Barnes, 2018). Since B did not get the answer, he asked again, and this time his question was unmarked.

\section{Extract 5}

A: $T u$ tiangnya.

that pole-nya

'That's the pole.' 
B: Hah?

hah

'Huh.'

A: Tiang.

Pole

'A pole.'

B: Bukan. Apa, apa Mas Jordan?

not what. what older brother Jordan

'No. What is it, Mas Jordan?'

C: Heh?

heh

'Huh?'

B: Apa sih itu?

whatsih that

'What is that, sih?'

C: Ininya?

this-nya

'This one?'

B: Heeh, apa?

heeh what

'Yes, what is it?'

$\begin{array}{clll}\text { C: Nggak } & \text { tau, } & \text { pintunya } & \text { ini. } \\ \text { not } & \text { know } & \text { door-its } & \text { this }\end{array}$

'I don't know. This is the door.'

In the cases of marked questions proceeded by unmarked questions, in the beginning, the speakers were not able to make the hearers get the point of the questions. Therefore, the speaker tried to deliver their ideas by using marked questions. Sih in marked questions makes the hearers notice that the speakers need an answer. In extracts 4 and 5, we can see that the hearers were cooperative to provide accurate answers. The response towards the marked questions is different from the unmarked questions. Sih was employed to build the sense of cooperativeness of the hearers.

\section{Positions of the Participants}

In both sequences of the organization of questions - whether marked questions followed by unmarked questions or the other way around - assymetrical positions among the speakers and the hearers occur in the marked questions. However, assymetrical postion is more obviously seen in marked questions (Hamdani \& Barnes, 2018).

In extract 1, the speaker uttered a marked question ini apa sih inih? Then, he got a response. He responded by asking another question, an unmarked question, ini apaan nih? This is the strategy of changing the question to carry on the interaction (Sidnell, 2015). When the speaker produced the marked question, the speaker did not know anything about it. He positioned himself as the one who was less knowledgable than the hearer. He had an idea that 
the hearer had information he was looking for. In the unmarked question, the speaker had information that the thing he asked for could be a pudding mold. However, he was willing to hear more accurate information. Therefore, he uttered an unmarked question. His epistemic position in unmarked question is different from the one in marked question. In this unmarked question, the speaker's position is closer to the hearer's level of knowledge.

In extract 2, surprisingly, there is a phenomenon of no-knowledge. This is in agreement of the study conducted by Lindström \& Karlsson (2016), who argue that speakers might say they do not know about such an issue when they are asked. This reflects speakers' dis ability to provide information or avoidance to discuss about a particular issue. The speaker asked a marked question, belajar apa aja sih? Here, he positioned himself as a party that did not know anything about what Ica (the hearer) had learnt. He also positioned Ica as a party that can provide some information for him. Neverthless, the hearer claimed she did not know. The speaker, then, produced an unmarked question, udah belajar apa aja? This question emphasizes that the speaker knew that the hearer learnt something even though he did not specifically know about the material. The speaker did not believe the hearer's claim of no-knowledge. In unmarked question, the speaker showed that he has a piece of information.

In extract 4, the speaker uttered an unmarked question, semut apa sih. The interloc utor did not answer the question by mentioning a type of ant. He just said digigit semut. The speaker asked again with marked question, semut apa sih. In the marked question, the speaker as ked to get information. He realized the hearer was more knowledgable than him. The hearer could supply such information. He, however, did not get information that he expected. To get c orrect information, he asked a marked question. The marked question implies speaker's acknowledgment that the hearer knows something that he does not know. Once again, the marked question reveals the participants' assymetrical positions.

\section{CONCLUSION}

The pattern of marked questions followed by unmarked questions dominates the pattern of questions and answers. In extracts 1-3 in which the marked questions were uttered first, the speakers show their eagerness to get information. The marked questions show the speakers are in the position of less knowledgable. The speakers, then, got answers but they still want to find more accurate answer. Here, the questions were given to ask for clarity (Brown, 2010). They produced unmarked questions to elic it more accurate answers. In unmarked questions, speakers' epistemic position is closer to the hearer. They know something from the responses given by the hearers tow ards their marked questions.

In the pattern of unmarked questions followed by marked questions, the speakers did not get any relevant information when they produced the unmarked questions. In extract 4 , the response to the marked question is to have another topic for discussion. In extract 5, the response is asking repetition because the hearer did not catch what the speaker said. Because of such kind of responses, the speakers asked with marked questions. In extract 4, it made the hearer focus on the topic, while in extract 5 , it aimed at repeating the question with special emphasize of the need to answer the question. Both marked questions were responded as what the speakers expected. In this question and answer pattern, there is no significant difference of speakers' epistemic position when they uttered marked and unmarked questions. 
This study reveals that marked and unmarked questions have different functions. Marked questions with sih function to seek for more definite and accurate answers. In this case sih indicates speakers' eagernes to receive answers. The findings are relevant to the study conducted by Djenar et al. (2018) \& Sari (2009).

\section{NOTE}

The author would like to thank an anonymous reviewer for very helpful comments on theearlier draft.

\section{REFERENCES}

Biber, D., Johansson, S., Leech, G., Conrad, S., \& Finegan, E. (1999). Longman grammar of spoken and written English. Longman.

Bongelli, R., Riccioni, I., Vincze, L., \& Zuczkowski, A. (2018). Questions and epistemic stance: Some examples from Italian conversations. Ampersand, 5 (March), 29-44. https://doi.org/10.1016/j.amper.2018.11.001

Brown, P. (2010). Questions and their responses in Tzeltal. Journal of Pragmatics. https://doi.org/10.1016/j.pragma.2010.04.003

Djenar, D. N., Ewing, M., \& Manns, H. (2018). Style and intersubjectivity in youth interaction (Issue February). Walter de Gruyter Inc. https://doi.org/10.1515/9781614516439

Enfield, N. J. (2010). Questions and responses in Lao. Journal of Pragmatics, 42(10), 26492665. https://doi.org/10.1016/j.pragma.2010.04.004

Gill, D. (2001). Reflexive Anaphor or Conjunctive Operator? Riau Indonesian Sendiri. In \& C. T. J. Cole, Peter; Hermon, Gabriella, Huang (Ed.), Long Distance Reflexives (pp. 83118). Emerald.

Hamdani, F., \& Barnes, S. (2018). Polar questions in colloquial Indonesian: A pilot study. Journal of Pragmatics, 132 (July 2018), 1-20.

Heritage, J. (2013). Action formation and its epistemic (and other) backgrounds. https://doi.org/10.1177/1461445613501449

Koshik, I. (2003). Wh-questions as challenges. Discourse Study, 5(1), 51-77.

Lindström, J., \& Karlsson, S. (2016). Tensions in the epistemic domain and claims of noknowledge: A study of Swedish medical interaction. Journal of Pragmatics, 106, 129147. https://doi.org/10.1016/j.pragma.2016.07.003

Mazeland, H. (2006). Conversation analysis. In K. Brown (Ed.), Encyclopedia of Language and Linguistics (pp. 153-163). Elsevier. https://doi.org/10.1016/B0-08-044854-2/00314-X

Miyake, Y. (2015). Pragmatic particles and information structure in colloquial Indonesian dialogue. Proceedings of the Second International Workshop on Information Structure of Austronesian Languages, 103-114.

Östman, Jan-Ola \&Virtanen, T. (2011). Text and discourse linguistics. In J. -O. Zienkowski, J an $\&$ Östman (Ed.), Discursive Pragmatics (pp. 266-285). John Benjamins.

Rühlemann, C. (2006). What can a corpus tell us about pragmatics? The Routledge Handbook of Corpus Linguistics, 319-332. https://doi.org/10.4324/9780203856949.ch21 
Sari, F. (2009). A prosodic aspect of the Indonesian pragmatic particle sih. https://doi.org/10.1017/CBO9781107415324.004

Schegloff, E. A. (2007). Sequence organization in interaction: A primer in conversation analysis I. In Sequence Organization in Interaction: A Primer in Conversation Analysis I (Issue January). Cambridge University Press. https://doi.org/10.1017/CBO9780511791208

Sidnell, J. (2015). Conversation analysis. In H. Heine, Bernd \& Narrog (Ed.), The Oxford handbook of linguistic analysis (pp. 167-192). Oxford University Press.

Sneddon, J. N. (2006). Colloquial Jakartan Indonesian. In The Australian National University. https://doi.org/10.1017/CBO9781107415324.004 